\title{
DISTRIBUSI SPESIES TERIPANG BERDASARKAN TIPE SUBSTRAT PADA EKOSISTEM PADANG LAMUN DI PERAIRAN NEGERI SULI
}

\author{
(Distribution of Sea Cucumber Based on Substrate Type \\ at Seagrass Ecosystem in Suli Waters)
}

\author{
Gratia D. Manuputty ${ }^{*}$ dan Yunita A. Noya \\ Jurusan Ilmu Kelautan Fakultas Perikanan dan Ilmu Kelautan Universitas Pattimura \\ "gd.manuputty@gmail.com,yunitanoya4@gmail.com \\ Corresponding author*
}

\begin{abstract}
ABSTRAK: Penelitian ini bertujuan untuk mengetahui penyebaran teripang berdasarkan karakteristik substrat yang ada di perairan intertidal Suli. Penelitian ini dilakukan di perairan Suli pada bulan November 2017. Data substrat yang diperoleh dianalisa dan diklasifikasikan berdasarkan Skala Shepards. Sedangkan data teripang diperoleh dari penelitian sebelumnya, dimana sampel teripang yang diperoleh kemudian dianalisa pada laboratorium untuk mengidentifikasi spesies yang ditemukan, berdasarkan analisa bentuk spikula secara mikroskopis. Data dipadukan untuk digunakan dalam membuat peta distribusi teripang berdasarkan karakter substrat yang ada. Data dianalisa secara deskriptif. Teridentifikasi 14 spesies teripang pada ekosistem padang lamun perairan Suli yang tersebar pada berbagai jenis substrat. Tipe substrat pada lokasi penelitian didominasi oleh susbtrat berpasir, dengan variasi substrat antara lain: pasir bercampur pasir sedang, pasir bercampur pasir kasar, pasir kasar bercampur pasir, kerikil bercampur pasir halus, dan karang/patahan karang. Dari beberapa variasi ini, tipe substrat yang paling mendominasi adalah pasir kasar bercampur pasir. Hasil penelitian menunjukkan bahwa ada penyebaran beberapa jenis teripang pada substrat tertentu, namun sebagian besar jenis teripang terdistribusi secara merata pada setiap jenis substrat. Jenis teripang Holothuria scabra, H. atra, dan Opheodosoma grisea ditemukan pada hampir semua tipe substrat.
\end{abstract}

Kata Kunci: teripang, substrat, distribusi, ekosistem lamun, Suli

ABSTRACT: This study aims to determine the distribution of sea cucumber based on the characteristics of the substrate in the intertidal waters of Suli. This research was conducted in the waters of Suli in November 2017. Substrate data were analyzed and classified based on Shepards Scale, while the data of sea cucumber were obtained from previous study where samples were analyzed in the laboratory to identify the species based on the shapes of sea cucumber spicules, microscopically. The data were combined to plot the distribution of sea cucumber based on existing substrate characters. Data were analyzed descriptively. Approximately 14 species identified were scattered on various types of substrate. The substrate were dominated by sandy substrate, varied from medium sand, very coarse sand (dominant), coarse sand, gravel mixed with fine sand, and coral fragments. The result showed that a number of sea cucumbers species were spoted on certain substrates, however, lots of species habitually distributed on each type of substrate. Spesies of Holothuria scabra, H. atra, and Opheodosoma grisea were distributed at majority substrates types.

Keywords: sea cucumber, substrates, distribution, seagrass ecosystem, Suli 


\section{PENDAHULUAN}

Teripang merupakan salah satu sumberdaya perairan yang memiliki peranan ekologis dan nilai ekonomis (Purcel et al., 2012a; Pattinasarany dan Manuputty, 2018). Teripang dimanfaatkan oleh masyarakat untuk dikonsumsi maupun dijual (Sulardiono, 2016; Sujarta dan Indrayani, 2016). Hewan ini berasal dari filum Echinodermata atau hewan berkulit duri. Teripang tergolong sebagai hewan pemakan serasah (deposit feeder) dimana teripang dapat mengolah substrat dari habitatnya menjadi sumber makanan, serta berfungsi secara ekologi sebagai penyedia pangan bagi biota laut pemangsa di sekitarnya dalam bentuk telur dan larva teripang (Darsono, 2007). Teripang menyukai hidup pada perairan dangkal, biasanya kurang dari $20 \mathrm{~m}$, pada daerah-daerah yang terlindungi, dengan kandungan nutrien yang tinggi, dan dapat hidup beradaptasi pada berbagai habitat yang meliputi habitat berlumpur, berpasir, berbatu, koral, padang lamun dan daerah pertumbuhan algae (James, 1994; James et al., 1994; Massin, 1999; Agudo, 2006). Teripang biasanya hidup membenam pada substrat dan sewaktu air surut spesies ini keluar pada posisi setengah membenam.

Perairan Suli berada pada teluk semi terbuka yang dipengaruhi oleh dinamika fisik air laut, sehingga zona intertidalnya memiliki dinamika yang sangat tinggi dari musim ke musim. Dinamika ini juga diduga mempengaruhi tipe substrat dasar yang bervariasi dan penyebaran beberapa kelompok hewan yang hidupnya terkait dengan substrat, seperti teripang.

Kehidupan teripang berkaitan dengan substrat (Hartati et al., 2017; Silaen $d k k$., 2018) karena selain sebagai hewan bentik, teripang merupakan pemakan serasah. Perairan intertidal di Suli yang memiliki beberapa karakteristik substrat diduga dapat mempengaruhi penyebaran beberapa jenis teripang. Untuk itu diperlukan data dan informasi tentang keberadaan teripang di perairan Suli yang berguna bagi masyarakat sekitar. Penelitian ini bertujuan untuk mengetahui penyebaran jenisjenis teripang berdasarkan karakteristik substrat yang ada di perairan intertidal Suli.
DOI: https://doi.org/10.30598/TRITONvol15issue2page76-81

\section{METODE PENELITIAN}

Penelitian ini dilakukan di perairan Suli pada bulan November 2017. Analisa substrat dilakukan pada Laboratorium Manajemen Sumberdaya Perairan Fakultas Perikanan dan Ilmu Kelautan. Alat dan bahan yang digunakan dalam penelitian ini antara lain: GPS, meter roll, tali, sediment corer, sediment shaker, toples sampel, dan kamera. Sedangkan bahan yang digunakan adalah plastik sampel, karet gelang, spidol permanen, dan data sheet.

Data yang digunakan dalam penelitian ini terbagi atas dua, yaitu data primer dan data sekunder. Data primer antara lain berupa data jenis substrat, sedangkan data sekunder yang digunakan antara lain data keterdapatan teripang pada lokasi yang diperoleh dari penelitian sebelumnya pada bulan September-Oktober 2017 berdasarkan hasil penelitian Manuputty et al. (2019), tabel pasang surut, serta berbagai penelitian dan sumber pustaka yang relevan.

Data substrat dan jenis teripang diambil pada saat air surut. Kedua data diambil secara purposive berdasarkan karakter substrat yang ada, dan sampel teripang dikoleksi secara bebas pada area penelitian yang ada, yaitu mengambil setiap jenis yang diperoleh berbeda pada setiap area yang dituju. Pengambilan sampel teripang dilakukan pada malam hari.

Data substrat yang diperoleh dianalisa dan diklasifikasikan berdasarkan Skala Shepards. Data substrat kemudian dipadukan dengan data distribusi substrat untuk digunakan dalam membuat peta distribusi teripang berdasarkan karakter substrat yang ada. Data dianalisa secara deskriptif. Hasil analisa dibuat dalam bentuk peta distribusi jenis teripang berdasarkan tipe substrat yang ada.

\section{HASIL DAN PEMBAHASAN}

Penelitian ini berlokasi di ekosistem padang lamun perairan Desa Suli, yang secara astronomis terletak pada $128^{\circ} 18^{\prime} 7^{\prime}$ 'BT$128^{\circ} 18^{\prime} 24^{\prime \prime}$ BT dan $3^{\circ} 37^{\prime} 32^{\prime \prime} L S-3^{\circ} 37^{\prime} 47^{\prime \prime} L S$. Manuputty et al. (2019) mengemukakan terdapat 14 spesies teripang yang diperoleh di ekosistem padang lamun perairan Desa Suli. Berdasarkan hasil identifikasi dan klasifikasi komposisi jenis teripang, ke-14 jenis teripang 
yang ditemukan di ekosistem padang lamun perairan Desa Suli tergolong di dalam 2 Ordo, 3 Famili, dan 5 Genus. Ke-empatbelas spesies tersebut antara lain: Actinopyga ehinites, A. lecanora, A. miliaris, Bohadschia marmorata, B. vitiensis, Holothuria arenicola, $H$. atra, $H$. coluber, $H$. hilla, $H$. lesson, $H$. scabra, Stichopus chloronotus, S. Horrens, dan Opheodesoma grisea.

Berdasarkan hasil identifikasi dan klasifikasi substrat berdasarkan skala Shepards, dominasi substrat pada lokasi penelitian yaitu substrat berpasir, dengan variasi substrat antara lain: pasir bercampur pasir sedang, pasir bercampur pasir kasar, pasir kasar bercampur pasir, kerikil bercampur pasir halus, dan karang/patahan karang (Gambar 1). Tipe substrat yang paling mendominasi adalah pasir kasar bercampur pasir. Variasi substrat bisa terjadi akibat pertemuan tiga ekosistem pesisir penting pada wilayah penelitian, yaitu mangrove, lamun, dan terumbu karang. Substrat yang mendekati ekosistem mangrove bercampur dengan pasir halus, namun didominasi kerikil yang merupakan patahan-patahan karang mati, Berdasarkan hasil penelitian, terlihat bahwa ada penyebaran beberapa jenis teripang pada substrat tertentu, namun sebagian besar jenis teripang terdistribusi secara merata pada setiap jenis substrat (Gambar 2). Pada gambar 2 memperlihatkan bahwa jenis teripang Holothuria scabra, H. atra, dan Opheodosoma grisea ditemukan pada hampir semua tipe substrat, dan jumlahnya juga ditemukan lebih tinggi dibandingkan jenis lain. Walau demikian, hasil analisa hubungan keterdapatan teripang dengan tipe substrat tidak menunjukkan korelasi yang nyata untuk setiap jenis yang ada. Menurut Purcell, et al. (2012b), beberapa jenis teripang memiliki kecenderungan pada habitat yang lebih keras seperti karang atau rataan karang, sedangkan lainnya memiliki kecenderungan untuk berada di substrat yang lebih lunak misalnya seperti pasir berlumpur. Selain itu juga, sebagian jenis ditemukan berasosiasi dengan padang lamun ataupun keduanya (padang lamun dan karang).

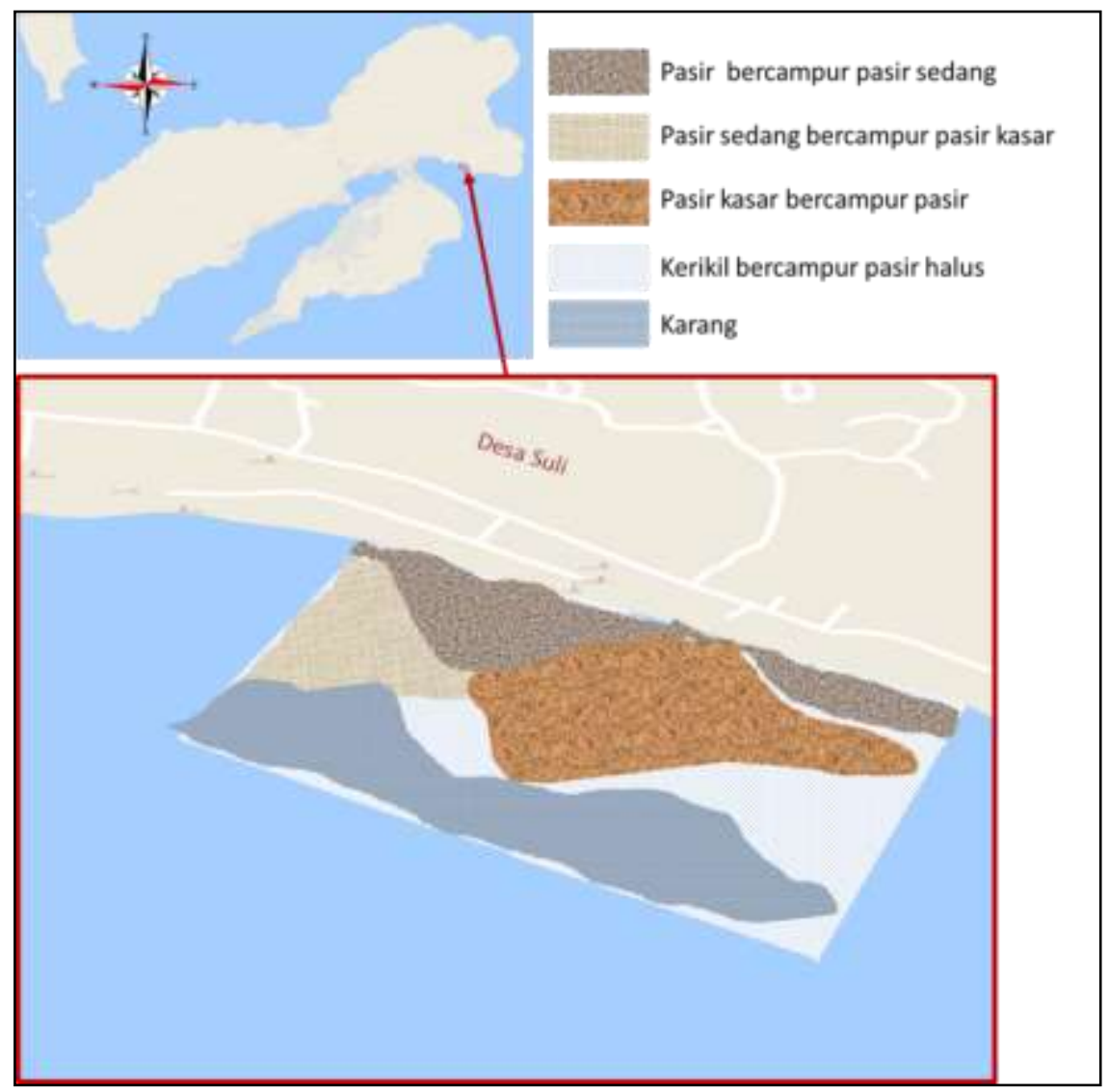

Gambar 1. Peta sebaran susbtrat pada lokasi penelitian 
Jenis teripang dari genus Actinopyga memiliki kecenderungan untuk berada pada kedua tipe habitat, sedangkan jenis teripang dari genus Bohadschia lebih cenderung berada pada substrat yang lebih lunak seperti pasir bercampur lumpur atau pasir halus, karena tingkah laku jenis teripang ini yang lebih suka membenamkan diri pada lumpur selama siang hari. Sifat dan kecenderungan ini juga dimiliki oleh jenis $H$. scabra. Berbeda dengan jenis lainnya, jenis $H$. atra umumnya selalu ditemukan pada siang hari dan cenderung tersebar pada substrat yang lebih keras atau kasar. $H$. coluber dan $O$. grisea cenderung untuk berada pada rockpool ataupun di balik batuan yang ada di padang lamun. Jenis $O$. grisea umumnya ditemukan melimpah pada hampir semua lokasi dan dapat ditemukan sepanjang hari. Jenis-jenis dari genus Stichopus memiliki kecenderungan untuk berada pada substrat yang keras/kasar, walaupun ada juga yang ditemukan di substrat berpasir dan padang lamun. $S$. horrens memiliki kebiasaan bersembunyi di balik retakan karang pada siang hari dan mencari makan pada malam hari.
Teripang merupakan deposit feeder yang memanfaatkan plankton, berbagai material organik dan detritus yang terdapat pada sedimen antara lain berbagai jenis plankton, polichaeta, protozoa, copepoda, cangkang moluska, dan fecal pelet hewan lain maupun fecal peletnya sendiri (Hammond, 1983; Zhou et al., 2006; Zamora and Jeffs, 2011). Sumber makanan teripang bersifat benthik dan terdapat di bawah tubuh daripada dalam kolom air maupun di atas tubuh menyebabkan teripang mengalami perubahan morfologi dimana mulut terdapat pada bagian ventral (Lawrence, 1987). Ekosistem seperti lamun, terumbu karang, maupun mangrove mampu menyediakan sumber makanan yang dibutuhkan teripang. Pada lokasi dengan substrat pasir bercampur pasir kasar dan pasir sedang yang tidak terlalu didominasi tumbuhan lamun dan masih terkena pengaruh surut air dan aliran air tawar dari sungai, sehingga diduga mempengaruhi jumlah jenis teripang tersebar di lokasi tersebut. Kondisi ini menyebabkan perubahan suhu dan salinitas yang drastis serta berkurangnya ketersediaan sumber makanan bagi teripang.

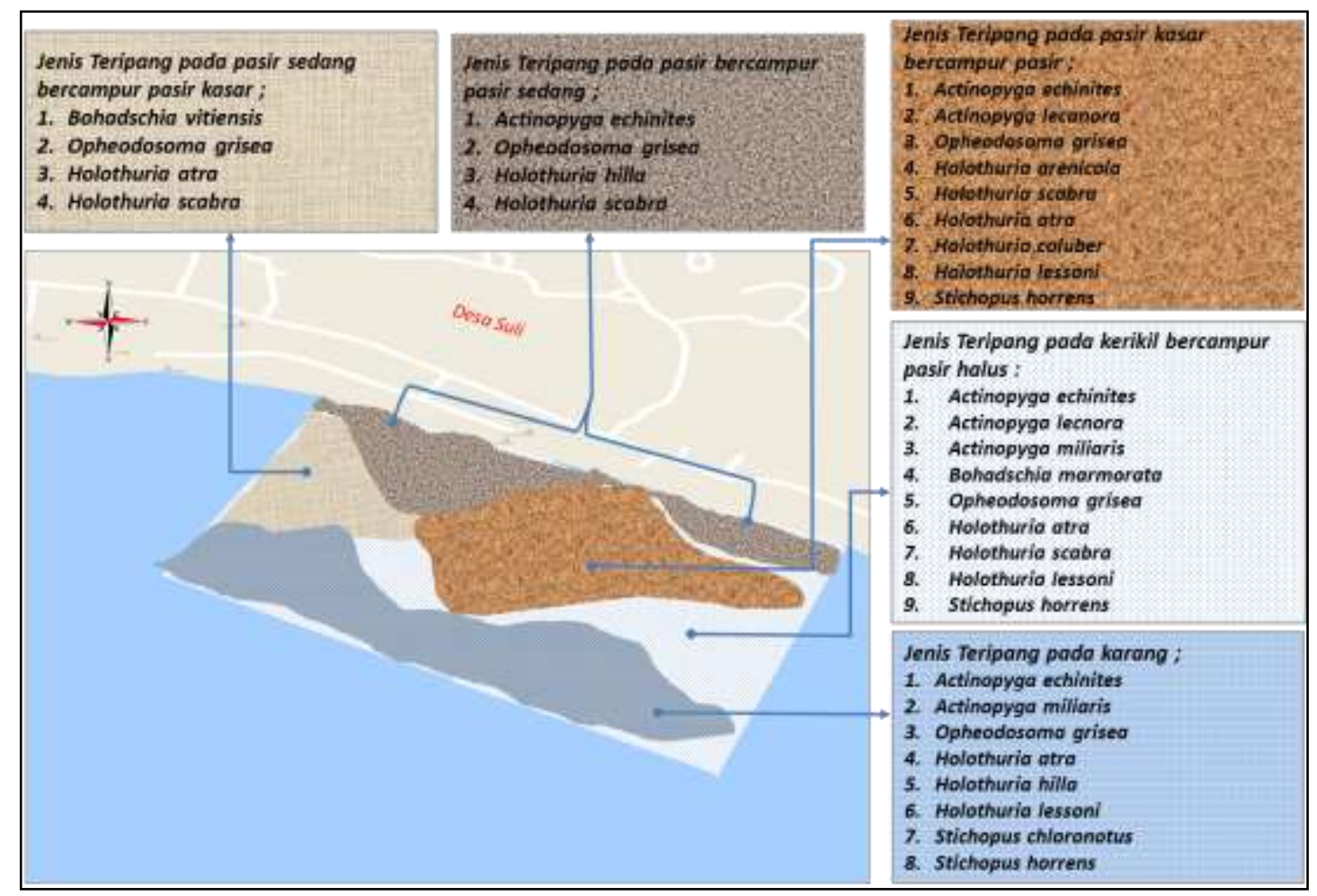

Gambar 2. Peta Distribusi Jenis Teripang Berdasarkan Tipe Substrat 
Substrat merupakan media hidup teripang sebagai organisme bentik. Berbagai pemanfaatan yang dilakukan di wilayah pesisir dapat berakibat positif maupun negatif terhadap keberadaan sumberdaya pesisir dalam hal ini teripang. Pemanfaatan teripang yang berlebih baik untuk dikonsumsi maupun di jual dapat mengurangi populasi teripang di perairan. Perubahan substrat akibat aktivitas masyarakat sekitar seperti pengambilan pasir pantai juga dapat mengakibatkan perubahan habitat teripang yang nantinya dapat berpengaruh pada keberadaan teripang tersebut. Substrat berhubungan erat dengan kebiasaan hidup seperti mencari makan di malam hari dan membenamkan diri di siang hari. Aktivitas membenamkan diri ini lebih berkaitan erat dengan suhu. Jika suhu meningkat, teripang kecil akan seharian membenamkan dirinya di dalam substrat. Bagi teripang yang menghuni habitat dengan tipe substrat kasar, maka teripang akan bersembunyi di balik karang. Bila suhu air meningkat hingga lebih dari $30^{\circ} \mathrm{C}$ teripang masih tetap di permukaan namun bila suhu air turun di bawah $28^{\circ}-29^{\circ} \mathrm{C}$ maka teripang akan membenam dengan tidak mengikuti pola pembenaman dirinya (Wolkenhauer, 2008; Purcell, 2010).

\section{KESIMPULAN DAN SARAN}

Jumlah spesies teripang yang diperoleh di daerah intertidal perairan Desa Suli terdapat 14 jenis, dengan substrat yang didominasi oleh susbtrat berpasir, dengan variasi substrat antara lain: pasir bercampur pasir sedang, pasir bercampur pasir kasar, pasir kasar bercampur pasir, kerikil bercampur pasir halus, dan karang/patahan karang. Penyebaran beberapa jenis teripang terjadi pada substrat tertentu, namun sebagian besar jenis teripang terdistribusi secara merata pada setiap jenis substrat. Jenis teripang Holothuria scabra, $H$. atra, dan Opheodosoma grisea ditemukan pada hampir semua tipe substrat, dan jumlahnya juga ditemukan lebih tinggi dibandingkan jenis lain.

Adapun saran yang dapat diberikan berdasarkan hasil penelitian ini yaitu perlu adanya penelitian lanjutan mengenai potensi teripang dan kondisi substrat di perairan Suli secara terus menerus, mengingat tinggi aktivitas pemanfaatan teripang maupun aktivitas yang dapat merubah kondisi substrat. Variasi substrat pada ekosistem lamun menunjang kehidupan berbagai jenis teripang, sehingga diperlukan upaya untuk menjaga kelestarian ekosistem tersebut.

\section{DAFTAR PUSTAKA}

Agudo, N., 2006. Sandfish Hatchery techniques. Australian Centre for International Agricultural Research (ACIAR), the Secretariat of the Pacific Community (SPC) and the WorldFish Center.

Arakawa, A.Y. 1990. A Handobook on the Japanese Sea Cucumber - Its Biology, Propagation and Utilization. Midori-Shobo Publishers. Tokyo.

Darsono, P. 2007. Teripang (Holothuroidea): Kekayaan Alam Dalam Keragaman Biota Laut. Oseana 32 (2): 1-10.

Hammond, L. S. 1983. Nutrition of DepositFeeding Holothuroids and Echinoids (Echinodermata) from a Shallow Reef Lagoon, Discovery Bay, Jamaica. Marine ecology Progress Research 10: 297-305.

Hartati, R., Widianingsih, D. Pringgenis. 2005. Teknologi Penyediaan Pakan bagi Teripang Putih (Holothuria scabra). Laporan Kegiatan Program Hibah Bersaing. Dibiayai oleh Direktorat Jendral Pendidikan Tinggi Departemen Pendidikan Nasional sesuai Surat Perjanjian Pelaksanaan pekerjaan Penelitian No. 031/SPPP/PP/DP3M/IV/200 Tanggal 11 April 2005.

Hartati, R., Widianingsih, Trianto, A., Zainuri, M., Ambariyanto. 2017. The Abundance of Prospective Natural Food for Sea Cucumber Holothuria atra at Karimunjawa Island Waters, Jepara, Indonesia. Biodiversitas. https://doi.org/10.13057/biodiv/d180311.

James, D.B., 1994. Ecology of Commercially Important Holothurians of India. Bulletin Central Marine Fisheris Research Institution 46: 37-38.

James, D.B., M.E. Rajapandian, C.P. Gopinathan, B.K. Baskar. 1994. Breakthrough in Induced Breeding and Rearing of the Larvae and Juveniles of Holothuria (Metriatyla) scabra Jaeger at Tuticorin. Bulletin Central Marine Fisheris Research Institution 46: 66-70.

Lawrence, J. 1987. A functional biology of echinoderms. The Johns Hopkins University Press. Baltimore. 340 pp. 
Manuputty, G. D., M. M. Pattinasarany, G. V. Limmon, A. Luturmas. 2019. Diversity and abundance of Sea Cucumber (Holothuroidea) in Seagrass Ecosystem at Suli Village, Maluku, Indonesia. 2019 IOP Conf. Ser.: Earth Environ. Sci. 339012032

Massin, C., 1999. Reef-dwelling Holothuroidea (Echinodermata) of the Spermonde Archipelago (South-West Sulawesi, Indonesia). Zool. Verh. Leiden 329:1-144.

Mercier, A., S.C. Battaglene and J-F. Hamel. 1999. Daily Burrowing Cycle and Feeding Activity of Juvenile Sea Cucumbers Holothuria scabra in Response to Environmental Factors. Journal of Experimental Marine Biology and Ecology, 239: 125-156

Pattinasarany, M. M. \& G. D. Manuputty. 2018. Potensi Jenis Teripang Bernilai Ekonomis Penting di Ekosistem Padang Lamun Perairan Desa Suli Maluku Tengah. Jurnal PAPALELE 2(1): 1-7. ISSN 2580-0787.

Purcell, S.W. 2010. Diel Burying by the Tropical Sea Cucumber Holothuria scabra: Effects of Environmental Stimuli, Handling and Ontogeny. Marine Biology 157: 663-671.

Purcell, S. W., Hair, C. A., \& Mills, D. J. 2012a. Sea Cucumber Culture, Farming and Sea Ranching in the Tropics: Progress, Problems and Opportunities. In Aquaculture. https://doi.org/10.1016/j.aquaculture.2012.08. 053

Purcell, S.W., Y. Samyn, \& C. Conand. 2012b. Commercially Important Sea Cucumbers of the World. FAO Species Catalogue for Fishery Purposes. No. 6. Rome, FAO. 2012. $150 \mathrm{pp}$.
DOI: https://doi.org/10.30598/TRITONvol15issue2page76-81

Silaen, D. B., I. W. Arthana, S. A. Saraswati. 2018. Distribusi Teripang (Holothuroidea) pada Perairan Pesisir Nusa Lembongan, Kecamatan Nusa Penida, Kabupaten Klungkung, Bali. Journal of Marine and Aquatic Science 4(2): 263-270.

Sujarta, P \& E. Indrayani. Pengetahuan Masyarakat Lokal Tentang Keragaman Teripang dan Pemanfaatannya di Pesisir Tablasupa, Depapre, Kabupaten Jayapura, Papua. Jurnal Biologi Papua 8(2):62-67. E-ISSN: 25030450.

Sulardiono, B. 2016. Potensi Pemanfaatan Teripang (Holothurians) di Perairan Karimunjawa, Kabupaten Jepara, Provinsi Jawa. BULETIN OSEANOGRAFI MARINA. https://doi.org/10.14710/buloma.v5i1.11298.

Wolkenhauer, S. M. 2008. Burying and Feeding Activity of Adult Holothuria scabra (Echinodermata: Holothuroidea) in a Controlled Environment. SPC Beche-de-mer Information Bulletin 27:25-28.

Zamora, L. N. and A. G. Jeffs. 2011. Feeding, Selection, Digestion and Absoption of Organic Matter from Mussel Waste of Juveniles of the Deposit-feeding Sea Cucumber Australostichopus mollis. Aquaculture 317: 223-228.

Zhou, L., H. Yang, S. Liu, X. Yuan, Y. Mao, Y. Liu, $\mathrm{X}$. Xu and F. Zhang. 2006. Feeding and Growth on Bivalve Biodeposit by the Deposit Feeder Stichopus japonicus Selenka (Echinodermata: Holothuroidea) co-cultured in lantern net. Aquaculture 256: 510-520. 